\title{
Differences in Australian and New Zealand medicines funding policies
}

\section{Zaheer-Ud-Din Babar \\ Senior lecturer \\ Head of pharmacy practice \\ School of Pharmacy \\ University of Auckland \\ New Zealand}

Senior research fellow

Medical Sciences

Sansom Institute

University of South

Australia

Adelaide

\section{Key words}

cost of drugs,

Pharmaceutical Benefits

Scheme

Aust Prescr 2014:37:150-1

First published online

4 July 2014

\section{Agnes Vitry}

School of Pharmacy and

Australia and New Zealand are well known internationally for having implemented national medicines policies that aim for equitable access to cost-effective and safe medicines. However, each country adopted a different approach.

In 2011, Australia spent more than double what New Zealand spent on pharmaceuticals per capita. Australia spent US $\$ 587$ (around 22\% more than the Organisation for Economic Co-operation and Development (OECD) average) while New Zealand spent US $\$ 288$ (around $40 \%$ less than the OECD average). ${ }^{1}$ A 2011-12 analysis of the 73 individual drug-dose combinations that are prescribed the most often or account for the most expenditure in Australia showed that Australian prices were, on average, eight times higher than New Zealand's. If Australia adopted New Zealand's prices for 62 identical drug-dose combinations, which are available in both countries, the total Pharmaceutical Benefits Scheme (PBS) expenditure would be reduced by $A \$ 1.1$ billion a year. ${ }^{2}$

New Zealand is able to achieve savings because of a combination of program budgeting, tough price negotiations and different procurement mechanisms, such as competitive tendering. ${ }^{3}$ Some of these policies have been emulated with success in other countries. However, the New Zealand policies are criticised because fewer medicines, including new drugs, are subsidised compared to other countries. A comparative analysis of the approval and funding of new drugs showed that only 59 (43\%) of the 136 medicines listed in the Australian PBS between 2000 and

\section{In 2011 Australia spent US\$587 on pharmaceuticals per capita, while New Zealand spent US\$288} 2009 were listed in the New Zealand Pharmaceutical Schedule. The listings in New Zealand occurred, on average, 32.7 months after Australia. ${ }^{4}$ In another study comparing the funding of cancer drugs in 13 countries or regions, New Zealand was the country that reimbursed the fewest indications. ${ }^{5}$ These differences are partly due to the Pharmaceutical Management Agency of New Zealand (PHARMAC) operating on a capped budget. It therefore prioritises new drugs against each other and against access to all medicines. In Australia, the Pharmaceutical Benefits Advisory Committee (PBAC) also considers the cost-effectiveness of new drugs compared with current standard of care, but has no capped budget. The decision to subsidise an item has to be determined by the Minister for Health if the net cost to the PBS is greater than $\$ 20$ million per year.

Australia has introduced new pricing policies that involve price disclosure by manufacturers to the government, including incentives and discounts to pharmacies. Australian consumers support accelerating these price cuts, but there are concerns that they will affect the profitability of pharmacies., ${ }^{6,7}$

Only a minority of new drugs provide a definite therapeutic advantage over standard treatments. Of the 217 approvals by the Australian Therapeutic Goods Administration between 2005 and 2007, only seven were rated as important therapeutic innovations. ${ }^{8}$ Most of the drugs funded in Australia and not in New Zealand were additions to an existing therapeutic class rather than new drugs providing important therapeutic benefits. ${ }^{4} \mathrm{New}$ Zealand is less likely to fund 'me too' products.

There is a dearth of research on whether or not the lack of access to some innovative medicines in New Zealand, or switching patients to different brands of medicines, adversely affects patient outcomes. On the other hand, New Zealanders may have access to some forms of treatment that are not funded in Australia. For example, insulin pumps are subsidised for all patients with type 1 diabetes in New Zealand, but only in children and adolescents under 18 years in Australia. There are benefits if unnecessary new drugs are not funded and the savings are allocated to more effective interventions. New Zealand has chosen to keep lower co-payments for prescriptions (NZ\$5 or less per script for most people) than in Australia (A $\$ 36.90$ for general patients or $A \$ 6$ for people with concession cards). The higher co-payments in Australia raise an important equity issue. A study showed that the $21 \%$ increase in the co-payments in 2005 adversely affected prescription medicine use. ${ }^{9}$

The population is ageing so the use of medicines will increase. Policy challenges ahead include growth in medicines expenditure, and consumer expectations that expensive specialised medicines will be funded by the government. In both countries, concerns have been expressed that the Trans-Pacific Partnership Agreement may affect access to affordable medicines 
by delaying the availability of generic medicines and by changing the funding policies.10,11 There is currently a move to harmonise the regulation of medicines in Australia and New Zealand with the creation of an Australia New Zealand Therapeutic Products Agency, but there are no current plans for harmonising funding models.

Until now there has been limited public debate on what the priorities are for Australia and New Zealand, including which decision criteria should be used to fund new drugs and at what price. In Australia, the PBAC publishes all its decisions as public documents, but the judgements embedded or implicit in these decisions are not widely debated. Although there is general satisfaction with access to medicines in Australia, there are concerns about delayed funding of new drugs. Industry-supported groups such as the Oncology Industry Taskforce and the Cancer Drugs Alliance argue that the listing of new cancer drugs on the PBS is worryingly low and call for reforms of the current funding processes. However, Australia pays more than other countries for drugs such as statins which, if they had been bought more cheaply, could have freed funds for new drugs.

In New Zealand there are concerns about access to high cost drugs, red tape in accessing unlisted treatments for individual patients, and equitable access for Maori and Pacific Island people. ${ }^{10}$ Many submissions to a public consultation by PHARMAC reported negative experiences in relation to the lack of access to some drugs and that the financial impact of decisions outweighed the consideration of other criteria. ${ }^{12}$ In response to this consultation, PHARMAC has announced that it will develop a proposal for change.

Public input and consumer engagement in debates around medicines policies and priorities are essential for ensuring the continuous commitment of health authorities to community values and maintaining public confidence in government decision-making processes. It is important that this debate is not driven by the pharmaceutical industry, which is mostly motivated by ensuring high profits for its new drugs whatever their effectiveness. Australian and New Zealand citizens need to be independently informed about the delicate balance between equity and costeffectiveness, and between individual and societal needs when funding new drugs. We need an open informed public debate on the choices that have to be made to ensure equitable and sustainable access to new drugs in the future. $<$

\section{Conflict of interest: none declared}

\section{REFERENCES}

1. Organisation for Economic Co-operation and Development Health at a glance 2013. OECD indicators. Paris: OECD Publishing: 2013.

www.oecd.org/els/health-systems/Health-at-a-Glance2013.pdf [cited 2014 Jun 20]

2. Duckett S, Breadon P, Ginnivan L, Venkataraman P. Australia's bad drug deal. High pharmaceutical prices. Melbourne: Grattan Institute; 2013

http://grattan.edu.au/static/files/assets/5a6efeca/ Australias_Bad_Drug_Deal_FINAL.pdf [cited 2014 Jun 20]

3. Cumming J, Mays N, Daubé J. How New Zealand has contained expenditure on drugs. BMJ 2010;340:c2441.

4. Wonder M, Milne R. Access to new medicines in New Zealand compared to Australia. N Z Med J 2011;124:12-28.

5. Cheema PK, Gavura S, Migus M, Godman B, Yeung L, Trudeau ME. International variability in the reimbursement of cancer drugs by publically funded drug programs. Curr Oncol 2012:19:e165-76.

6. Quilty D. Pharmaceuticals, pharmacists and profits: the Pharmacy Guild perspective [editorial]. Aust Prescr. First published online 2014 Jul 4.

7. Clarke P. Pharmaceuticals, pharmacists and profits: a health policy perspective [editorial]. Aust Prescr. First published online $2014 \mathrm{Jul} 4$.
8. Vitry Al, Shin NH, Vitre P. Assessment of the therapeutic value of new medicines marketed in Australia. J Pharm Policy Pract 2013;6:2.

9. Hynd A, Roughead EE, Preen DB, Glover J, Bulsara M, Semmens J. The impact of co-payment increases on dispensings of government-subsidised medicines in Australia. Pharmacoepidemiol Drug Saf 2008;17:1091-9.

10. Babar Z, Francis S. Identifying priority medicines policy issues for New Zealand: a general inductive study. BMJ Open 2014;4:e004415.

11. Hirono K, Gleeson D, Haigh F, Harris P. The Trans Pacific Partnership Agreement negotiations and the health of Australians: A policy brief. Centre for Health Equity Training, Research and Evaluation, Centre for Primary Health Care and Equity, UNSW Australia. Sydney: University of New South Wales; 2014 www.phaa.net.au/documents/140217\%20TPP-policy\%20 brief\%20FINAL.pdf [cited 2014 Jun 20]

12. Pharmaceutical Management Agency. PHARMAC's decision criteria: Summary of submissions. Wellington: PHARMAC; 2013. www.pharmac.health.nz/assets/decision-criteria-summaryof-submissions-2013-12.pdf [cited 2014 Jun 20] 